\title{
Spectral characterization of the effect of gas-water ratio on dissolved organic nitrogen variation along biological aerated filter for micropolluted source water pre-treatment
}

Jia Kang ( $\sim$ kangjia@ncwu.edu.cn )

North China University of Water Resources and Electric Power

Gang-fu Song

North China University of Water Resources and Electric Power

Shu-li Liu

North China University of Water Resources and Electric Power

Chu-qiong Song

North China University of Water Resources and Electric Power

\section{Xu Gao}

Chongqing Sino French Enviromental Protection Research and Development Center

\section{Research Article}

Keywords: spectral characterization, gas-water ratio, dissolved organic nitrogen, micro-polluted source water, biological aerated filter, parallel factor, fluorescence regional integration

Posted Date: April 21st, 2021

DOI: https://doi.org/10.21203/rs.3.rs-363881/v1

License: (c) (i) This work is licensed under a Creative Commons Attribution 4.0 International License.

Read Full License

Version of Record: A version of this preprint was published at Environmental Science and Pollution Research on July 28th, 2021. See the published version at https://doi.org/10.1007/s11356-021-15528-4. 


\section{Abstract}

In order to improve our understanding of dissolved organic nitrogen (DON) variation characteristics in the biological aerated filter (BAF) for drinking water treatment, this study focused on gas-water ratio, a controlling factor of BAF operation, to study spectral characteristics of DON under different gas-water ratio conditions $(0,0.5: 1,2: 1$ and 10:1). The variations of dissolved organic carbon (DOC) and DON concentrations showed that DOC removal efficiency was consistent with DON concentration, both of which increased with the increase of gas-water ratio, but the increase gradually reduced and was certain limited. Three-dimensional excitation-emission matrix (3D-EEM) spectroscopy combined with parallel factor (PARAFAC) model and fluorescence regional integration (FRI) technique were applied to analyze the effect of gas-water ratio on spectral characteristics of DON, PARAFAC analysis results identified the main component of DON were tryptophan and protein related substances. The resistances of various fluorescent substances in the FRI technique under the influence of gas-water ratio were shown as: protein substances $>$ humic acid and fulvic acid substances $\approx$ SMPs-like substances. Correlation analysis showed that the variation of FIS from PARAFAC model was consistent with corresponding normalized integration volume in FRI analysis under different gas-water ratios.

\section{Introduction}

With the development of industrialization, the amount and types of pollutants discharged into source water became more and more numerous and complex (Wu et al. 2019), biological aerated filter (BAF) was gradually introduced into drinking water treatment to treat micro-polluted source water due to its abundant biomass and high biological activity under oligotrophic condition (Takasaki et al. 1990; Liu et al. 2017).

In the biological treatment process, soluble microbial products (SMPs) were released by microbial degradation of organic matters through cell lysis, cell membrane diffusion, and anabolic loss accompanied (Kang et al. 2014). Some relevant literature confirmed that humic substances, proteins, and carbohydrates were the dominant components of SMPs (Shen et al. 2012; Cui et al. 2019). Dissolved organic nitrogen (DON) derived from SMPs was composed of a series of compounds containing nitrogencontaining functional groups, mainly including $\mathrm{NHs}$, aminos, nitriles, purines, pyrimidines, nitro compounds, etc. (Li et al. 2019b), and DON was confirmed to be an important part of SMPs (Kang et al. 2019). During the disinfection process, precursors of disinfection by-products in DON can react with chlorine or combined chlorine (chlorine dioxide, chloramine), and produced a series of nitrogen disinfection by-products with strong carcinogenicity, such as halogenated nitromethane, haloacetonitrile and nitrosamines (Chang et al. 2013). Moreover, the proteinaceous substances in the MBR have been confirmed to be the main pollutants causing nanofiltration membrane contamination in water treatment (Teng et al. 2020). Based on these results, it is particularly important to study the mechanism of DON production in biological treatment processes and to further study how to reduce DON production. 
Biofilter media (Zhang et al. 2015), reactor (Lu et al. 2015), influent quality (Xu et al. 2011), filtration velocity (Ma et al. 2016) and other factors (Liao et al. 2019; Hu et al. 2020b) all had important effects on the generation and utilization of DON in the biological treatment process, among them, gas-water ratio strongly influenced the community structure of dominant microorganisms directly due to the oxygen concentration fluctuation and oxygen mass transfer (Zhang et al. 2018; Li et al. 2019a). An appropriate gas-water ratio could slow down clogging, promote mass transfer, and improve microbial activity while scouring the aging biofilm (Zhang et al. 2018). Some published reports made clear that an appropriate gas-water ratio was existed in terms of nitrogen removal (Yue et al. 2018), manganese removal (Hasan et al. 2013), and $\mathrm{N}_{2} \mathrm{O}$ emissions (Yang et al. 2020) in the BAF process.

Three-dimensional excitation-emission matrix (3D-EEM) spectroscopy has been a powerful tool in environmental analysis to study the characteristics of dissolved organic matter (DOM). Through fluorescence signals of excitation and emission for each sample, 3D-EEM can provide fluorescent information about DOM such as protein, humic and fulvic acids (Carstea et al. 2010). Therefore, this method has been used to characterize samples from marine, aquatic and soil (Cao et al. 2019; Zhuang et al. 2021; Chai et al. 2019). For its role as an indicator of the treatment efficiency and water quality of both drinking water and wastewater treatment plants, 3D-EEM had also been adopted as a sufficiently sensitive method to analyze the DOM created during drinking water and wastewater treatment (Gone et al. 2009; Rodríguez-Vidal et al. 2020). Moreover, with the application of 3D-EEM in environmental research, parallel factor (PARAFAC) model and fluorescence regional integration (FRI) technique were proven to be suitable approaches to get insight into the compositions, variations, and characteristics of DON in drinking water biological treatment process (Zhang et al. 2019). These spectroscopy techniques provided a feasible approach to quantificationally examine the changes of chemical composition and structure of DON from the drinking water BAF.

The objective of this study is to explore spectral characterization of DON along the BAF using 3D-EEM combined with PARAFAC model and FRI technique, and to determine the variation characteristics of DON under different gas-water ratio conditions. A particular focus of this study is to improve our understanding of the fluorescence characteristics of DON under the influence of gas-water ratio through spectroscopic analysis. Moreover, through the consistency analysis of 3D-EEM results by PARAFAC model and FRI technique, the characteristics of these two analysis methods are determined.

\section{Materials And Methods}

\subsection{BAF reactor and experimental design}

The experiment in this study was conducted in an upward flow lab-scale BAF made of plexiglass with an inner diameter of $50 \mathrm{~mm}$ and an effective working volume of $12.17 \mathrm{~L}$ (Fig. 1). The internal space of the filter column can be divided into three zones structurally: gas and water distribution zone, supporting layer and filter zone, and water outlet zone. The bottom of the filter column was gas and water distribution zone with a height of $300 \mathrm{~mm}$, and supporting layer with a height of $150 \mathrm{~mm}$ above it, which 
was composed of almost circular pebbles. Filter layer above was filled with 2-5 $\mathrm{mm}$ shale ceramsite with a height of $800 \mathrm{~mm}$. Sampling holes were set equally along the media layer at $16 \mathrm{~cm}$ intervals for water sampling, and the interval was determined according to the study of Yu et al. (2008). A peristaltic pump (BT-100EA/153Yxx2PPS, Jieheng, China) was applied to maintain a filtration velocity of approximately 2 $\mathrm{m} / \mathrm{h}$. An air compressor (OLF-2530, Jiebao, China) was used to provide aeration and maintain the gaswater ratio in the BAF at 1:1-2:1, with which dissolved oxygen (DO) in the effluent was maintained at 6-7 $\mathrm{mg} / \mathrm{L}$. Backwashing was performed every other day. The reactor had been running stably for 6 months before experiment and drained before flows recommenced. BAF reactor was fed with synthetic micropolluted source water with dissolved organic carbon (DOC), $\mathrm{NH}_{4}{ }^{+}-\mathrm{N}, \mathrm{PO}_{4}{ }^{3-}-\mathrm{P}$ and DON concentrations 20, $10,0.2$ and $0 \mathrm{mg} / \mathrm{L}$, respectively. The influent $\mathrm{pH}$ was kept in the range of 7-8 by dosing $\mathrm{NaHCO}_{3}$ and monitored by a pH meter. Both chemical oxygen demand (COD) and $\mathrm{NH}_{4}{ }^{+} \mathrm{N}$ removal efficiencies exceeded $65 \%$ before experiment.

In the study, single factor experiment was applied and four gradients of gas-water ratios were set: 0, 0.5:1, 2:1 and 10:1. Sampling time was set on the second day after backwashing to ensure that the effluent was stable and up to standard. Sampling was taken once in each backwashing cycle.

\subsection{Sampling and measurement}

Water samples from different depths of filter layer under different gas-water ratios were obtained from the sampling taps, and were filtered with pre-washed $0.45 \mu \mathrm{m}$ cellulose acetate membranes (Anpel Co. Ltd., China) before measurement. The concentrations of $\mathrm{DOC}, \mathrm{NO}_{3}{ }^{-}, \mathrm{NO}_{2}{ }^{-}$, and $\mathrm{NH}_{4}{ }^{+}$were determined. Total dissolved nitrogen (TDN) was measured with alkaline potassium persulfate digestion UV spectrophotometry; $\mathrm{NO}_{3}{ }^{-}-\mathrm{N}$ was measured with UV spectrophotometry; $\mathrm{NO}_{2}{ }^{-}-\mathrm{N}$ was measured with $\mathrm{N}-(1-$ naphthyl)-ethylenediamine photometric method; and $\mathrm{NH}_{4}{ }^{+}-\mathrm{N}$ was measured with salicylate-hypochlorite spectrophotometry. These experiments were carried out according to the Chinese National Standard Methods (SEPA of China, 2002). DON was quantified as the difference between TDN and dissolved inorganic nitrogen (DIN): DON $=\mathrm{TDN}-\mathrm{NO}_{3}{ }^{-}-\mathrm{NO}_{2}{ }^{-}-\mathrm{NH}_{3} / \mathrm{NH}_{4}{ }^{+}$.

\subsection{D-EEM fluorescence spectroscopy}

Water samples were filtered with pre-washed $0.45 \mu \mathrm{m}$ cellulose acetate membranes (Anpel Co. Ltd., China) and then scanned with an F-7000 three-dimensional fluorescence spectrophotometer (Hitachi, Japan). The emission wavelength increased from 220 to $600 \mathrm{~nm}$ at $5 \mathrm{~nm}$ steps by varying the excitation wavelength incrementally from 200 to $450 \mathrm{~nm}$ at $5 \mathrm{~nm}$ steps. Excitation and emission slits were both set to a $5 \mathrm{~nm}$ band-pass, scanning speed was set at $12000 \mathrm{~nm} / \mathrm{min}$, and photomultiplier detector voltage was fixed at 700 V. A $1 \mathrm{~cm}$ optical path quartz cuvette was used for measurement. Raman and Raleigh scatter were removed for PARAFAC model and FRI technique by subtracting the response of fluorometer to a blank solution from the 3D-EEM spectra of water samples. The blank solution was prepared from Super-Q water with a resistivity of $18.25 \Omega \cdot \mathrm{cm}$. The 3D-EEM fluorescence spectrum data was processed and drawn by Origin 9.0 software (OriginLab Inc., USA). 


\subsection{FRI data processing}

FRI technique divided the 3D-EEM spectra into five regions that were related to aromatic protein (Regions I and II), fulvic acid-like substances (Region III), soluble microbial products (SMPs)-like substances (Region IV) and humic acid-like substances (Region V) (Chen et al. 2003). Integrating the cumulative volume beneath each excitation-emission area and normalizing these values to relative regional areas $\left(\mathrm{nm}^{2}\right)$.

\subsection{PARAFAC model}

PARAFAC model used an alternating least squares algorithm to minimize the sum of squared residuals in a trilinear model as well as reduced a 3D-EEM dataset into a set of trilinear terms and a residual array (Bro 1997; Bro and Kiers 2003). This model was achieved using N-way v.3.20 Toolbox (http://www.models.life.ku.dk/nwaytoolbox/download) based on MATLAB software.

\section{Results And Discussion}

\subsection{Performance of BAF reactor under different gas-water ratios}

Figure 2 shows the variations of DOC concentrations and DOC removal efficiencies along the BAF media layer when the gas-water ratio was set to $0,0.5: 1,2: 1$ and 10:1 respectively. Below the filter layer depth of $32 \mathrm{~cm}$, DOC concentrations dropped significantly, and corresponding DOC removal efficiencies increased. Above $32 \mathrm{~cm}$, DOC concentrations and removal efficiencies tended to stabilize. Therefore, DOC was mainly removed below the filter layer depth of $32 \mathrm{~cm}$. This was consistent with findings in the relevant literature. Due to the sufficient organic matter in the lower part of the filter, and the growth and metabolism of heterotrophic bacteria was vigorous, Fdz-Polanco et al. (2000) divided the filter layer into two different zones in a submerged biofilter in the case of COD: $\mathrm{NH}_{4}{ }^{+}-\mathrm{N}$ higher than 4 .

DOC concentrations in the effluent under gas-water ratios of $0,0.5: 1,2: 1$ and 10:1 were $8.60 \mathrm{mg} / \mathrm{L}, 7.58$ $\mathrm{mg} / \mathrm{L}, 7.22 \mathrm{mg} / \mathrm{L}$ and $7.04 \mathrm{mg} / \mathrm{L}$, respectively, and DOC removal efficiencies were $50.07 \%, 57.51 \%$, $64.18 \%$ and $68.11 \%$, respectively. With the increase of the gas-water ratio, DOC removal efficiencies gradually increased, thus the increase of gas-water ratio was conducive to improve DOC removal efficiency (Hasan et al. 2014). Liu et al. (2008) came to a consistent conclusion to this study in an upflow BAF packed with two layers media for tertiary treatment of textile wastewater secondary effluent, with the increase of DO concentrations from 2.4 to $6.1 \mathrm{mg} / \mathrm{L}$, the COD removal efficiencies were $39-53 \%$ and $64-88 \%$, respectively.

However, as the gas-water ratio increased, due to the saturation of DO concentration, DOC removal efficiency increase with limit (Hasan et al. 2011). Statistical analyses of Hasan et al. (2013) indicated insignificant effects of the different aeration rates $(0.3-2 \mathrm{~L} / \mathrm{min})$ on COD removal $(p>0.05)$ in a lab-scale BAF system for high-strength polluted drinking water. Further, Yang et al. (2017) concluded that gas-water 
ratio (3:1) was a relatively suitable operational condition for a BAF reactor treating municipal wastewater. In this study, when the gas-water ratio increased from 0 to $0.5: 1,2: 1$ and 10:1 in turn, DOC removal amount increased by $0.84(\mathrm{mg} / \mathrm{L}) /(\mathrm{L} / \mathrm{h}), 0.46(\mathrm{mg} / \mathrm{L}) /(\mathrm{L} / \mathrm{h})$ and $0.067(\mathrm{mg} / \mathrm{L}) /(\mathrm{L} / \mathrm{h})$, respectively, and when the gas-water ratio increased from 2:1 to 10:1, the amount of DOC removal was weaker than before, so the optimal gas-water ratio in this study can be considered as 2:1.

\subsection{Influence of gas-water ratio on the concentration of DON in BAF}

Accompanied by the microbial metabolism in BAF, microorganisms degraded organic matter and ammonia nitrogen while converting DIN to DON, causing a deviation between TDN and DIN, and the deviation was DON. Some previous studies have confirmed the existence of DON, and elaborated DON generation mechanism (Kang et al. 2019; Hu et al. 2020a).

In this study, the concentration of DON producing in BAF showed similar characteristics under different gas-water ratio conditions (Fig. 3), rose significantly below $16 \mathrm{~cm}$, and maintained a relatively stable level above $16 \mathrm{~cm}$. This result was consistent with the DOC removal process. This was because that the vigorous microbial metabolism in the depth range below $16 \mathrm{~cm}$. Further, due to the simultaneous existence of DON production and degradation, coupled with that biofilter media (Zhang et al. 2015), reactors (Lu et al. 2015), influent quality (Xu et al. 2011), filtration velocity (Ma et al. 2016) etc. all having effects on the generation and utilization of DON, it was reasonable to find inconsistent conclusions in the relevant literature (Zhang et al. 2015).

As the gas-water ratio increased, DON concentration gradually increased. When the gas-water ratio was 0 , $0.5: 1,2: 1$, and 10:1, the average concentration of DON in BAF was $0.84 \mathrm{mg} / \mathrm{L}, 1.08 \mathrm{mg} / \mathrm{L}, 1.16 \mathrm{mg} / \mathrm{L}, 1.34$ $\mathrm{mg} / \mathrm{L}$, respectively, DO increase was accompanied by more vigorous microbial metabolic activity. When the gas-water ratio increased from 0 to $0.5: 1,2: 1$ and 10:1, the average concentration of DON in the depth range of $16-80 \mathrm{~cm}$ was $0.88 \mathrm{mg} / \mathrm{L}, 1.13 \mathrm{mg} / \mathrm{L}, 1.12 \mathrm{mg} / \mathrm{L}$, and $1.38 \mathrm{mg} / \mathrm{L}$, respectively, the growth intensity of DON was $0.13(\mathrm{mg} / \mathrm{L}) /(\mathrm{L} / \mathrm{h}), 0.013(\mathrm{mg} / \mathrm{L}) /(\mathrm{L} / \mathrm{h}), 0.005(\mathrm{mg} / \mathrm{L}) /(\mathrm{L} / \mathrm{h})$, respectively, the growth intensity gradually decreased. Since the production and degradation of DON and DOC removal were closely related to the microbial metabolism process in BAF, the effect of gas-water ratio on DOC removal efficiency and DON concentration were consistent.

\subsection{Influence of gas-water ratio on the composition of DON in BAF}

Gas-water ratio can not only affect the concentration distribution of DON in BAF, but also cause the changes of DON composition. In this study, 3D-EEM spectroscopy coupled with PARAFAC model and FRI technique were used to analyze the composition characteristics of DON under the influence of gas-water ratio (3D-EEM spectra under different gas-water ratio conditions are shown in the supplementary materials). 


\subsubsection{Componential characterization of DON by PARAFAC model}

Both core consistency diagnostic (Bro and Kiers 2003) and half-split analysis (Stedmon and Bro 2008) were used to determine the optimal component number of fluorescent substances in the 3D-EEM spectra under different gas-water ratio conditions, and two-component model was proved to be validated. 3DEEM spectra and wavelength loadings of the two components decomposed by PARAFAC model are shown in Fig. 4. The peaks of Component 1 (C1) were located at Ex/Em $=250 \mathrm{~nm} / 415 \mathrm{~nm}$ and 320 $\mathrm{nm} / 415 \mathrm{~nm}$, representing fulvic acid and humic acid (Aryal 2009); the peaks of Component 2 (C2) were at $\mathrm{Ex} / \mathrm{Em}=230 \mathrm{~nm} / 340 \mathrm{~nm}$ and $280 \mathrm{~nm} / 340 \mathrm{~nm}$, represented substances related to tryptophan and protein (Yamashita and Tanoue 2003).

The variations of fluorescence intensity score (FIS) under different gas-water ratios by PARAFAC model are shown in Fig. 5. When gas-water ratio was set at 0.5:1 or 10:1, FIS of C1 first decreased and then increased with the increase of filter depth. And when gas-water ratio was at 0 or 2:1, the FIS fluctuated within a certain range, showing an overall upward trend. In general, under different gas-water ratio conditions, C1 showed an overall upward trend as the depth of the filter layer increased. For C2, FIS gradually increased with the increase of filter depth, but the upward trend became less and less obvious with the increase of gas-water ratio, and the FIS increment in the effluent decreased gradually compared with the increment in the influent.

\subsubsection{Componential characterization of DON by FRI technique}

FRI technique divided the 3D-EEM spectrum into five regions, each region represented specific component of DOM. The normalized integration volumes (NIV) ( $\left.\emptyset_{i, n}\right)$ of each region for samples from different media depths of BAF under different gas-water ratios are shown in Fig. 6.

When the gas-water ratio was $0, \emptyset_{\mathrm{l}+\mathrm{II}}$ (representing protein-like substances) increased along the filter layer depth, and the increasing trend slowed down as the gas-water ratio promoted. When the gas-water ratio increased from 0 to 0.5:1, 2:1 and 10:1, the increments of $\emptyset_{\mathrm{l}+\mathrm{II}}$ after BAF treatment were $1.31 \times 10^{7}$ AU-nm²$(\mathrm{mg} / \mathrm{L})^{-1}, 1.29 \times 10^{7} \mathrm{AU}-\mathrm{nm}^{2}-(\mathrm{mg} / \mathrm{L})^{-1}, 0.49 \times 10^{7} \mathrm{AU}-\mathrm{nm}^{2}-(\mathrm{mg} / \mathrm{L})^{-1}$ and $-0.37 \times 10^{7} \mathrm{AU}-\mathrm{nm}^{2}-(\mathrm{mg} / \mathrm{L})^{-1}$, respectively, the increment percentages compared with influent were $71.98 \%, 92.81 \%, 29.17$ and $-20 \%$ respectively.

The effect of gas-water ratio on $\emptyset_{\text {III }+\mathrm{V}}$ (representing fulvic acid-like and humic acid-like substances) was

similar to that on $\emptyset_{\mathrm{l}+\mathrm{II}}$. With the increase of gas-water ratio, the variation of $\emptyset_{\mathrm{III+V}}$ along the filter layer from gradually increase to relatively stable, when the gas-water ratio increased from 0 to 0.5:1, 2:1 and 10:1, the increments of $\emptyset_{\text {III }+\mathrm{V}}$ were $0.52 \times 10^{7} \mathrm{AU}-\mathrm{nm}^{2}-(\mathrm{mg} / \mathrm{L})^{-1}, 0.46 \times 10^{7} \mathrm{AU}-\mathrm{nm}^{2}-(\mathrm{mg} / \mathrm{L})^{-1}, 0.24 \times 10^{7} \mathrm{AU}-\mathrm{nm}^{2}-(\mathrm{mg} / \mathrm{L})^{-1}$ and $0.14 \times 10^{7} \mathrm{AU}-\mathrm{nm}^{2}-(\mathrm{mg} / \mathrm{L})^{-1}$, respectively, and the increment percentage of $\emptyset_{\mathrm{III}+\mathrm{V}}$ after BAF treatment were $31.32 \%$, $30.46 \%, 13.64$ and $-7.61 \%$, respectively. Compared with protein-like substances, gas-water ratio has a weaker effect on fulvic acid and humic acid-like substances.

$\emptyset_{\text {IV }}$ (representing SMPs-like substances) also showed similar changes with $\emptyset_{I+\mathrm{Il}}$ and ${ }^{\emptyset_{\mathrm{III}+\mathrm{V}}}$ along the filter layer depth, when the gas-water ratio increased from 0 to $0.5: 1,2: 1$ and 10:1, the increment of $\emptyset_{\mathbb{V}}$ after BAF treatment were $0.47 \times 10^{7} \mathrm{AU}-\mathrm{nm}^{2}-(\mathrm{mg} / \mathrm{L})^{-1}, 0.30 \times 10^{7} \mathrm{AU}-\mathrm{nm}^{2}-(\mathrm{mg} / \mathrm{L})^{-1}, 0.17 \times 10^{7} \mathrm{AU}-\mathrm{nm}^{2}-(\mathrm{mg} / \mathrm{L})^{-1}$ and $0.05 \times 10^{7} \mathrm{AU}-$ $\mathrm{nm}^{2}-(\mathrm{mg} / \mathrm{L})^{-1}$, the increment percentages were $33.33 \%, 29.6 \%, 16.67 \%$ and $5.26 \%$, respectively. The effect of gaswater ratio on fulvic acid and humic acid-like substances was equivalent to the effect on SMPs-like substances. 
In summary, the resistances of protein-like substances, fulvic acid-like and humic acid-like substances, and SMPs-like substances to gas-water ratio were expressed as: protein substances $>$ humic acid and fulvic acid substances $\approx$ SMPs-like substances. The variations of FIS analyzed by PARAFAC model were consistent with the analysis result of FRI technique.

With the promotion of gas-water ratio, $\emptyset_{\mathrm{i}}$ getting lower and lower, and it represented the variation characteristics of DON with fluorescent properties. Within the gas-water ratio range of this study, its promotion was conducive to decrease fluorescent protein substances.

3.4 Relationship between 3D-EEM results from PARAFAC model and FRI technique

In this study, PARAFAC model and FRI technique were used to analyze the 3D-EEM spectra under different gaswater ratios to determine the spectral variation of DON in BAF. Further correlation analyses on the corresponding components of PARAFAC model and FRI technique were carried out to explore the difference between the two analysis methods.

The correlation between PARAFAC model and FRI technique on corresponding components are summarized in Fig. 7. In the PARAFAC analysis, C1 represented fulvic acid or humic acid, thus correlations between FIS-1 and $\emptyset_{[\mathrm{In, \textrm {n }}}, \emptyset_{\mathrm{V}, \mathrm{n}}, \emptyset_{\mathrm{III}+\mathrm{V}, \mathrm{n}}$ were analyzed respectively to clarify the substance represented by C1. FIS-1 showed the strongest correlation $\left(R^{2}=0.957\right)$ with $\emptyset_{\mathrm{V}, \mathrm{n}}$, followed by $\emptyset_{\mathrm{III}+\mathrm{V}, \mathrm{n}}\left(\mathrm{R}^{2}=0.487\right)$ and finally $\emptyset_{\mathrm{III,n}}\left(\mathrm{R}^{2}=0.150\right)$. The strong and comparable correlation $\left(\mathrm{R}^{2}\right)$ between FIS-1 and $\emptyset_{\mathbb{V}, \mathrm{n}}$ in this study implied that the FIS of C1 in PARAFAC model corresponded to the NIV in Region V (humic acid) of FRI technique (Fig. 7(a)). Moreover, FIS-2

was significantly correlated with $\emptyset_{[\mathrm{I}+\mathbb{\mathbb { V }}, \mathrm{n}}$ with $\mathrm{R}^{2}=0.912$ (Fig. 7(b)), the result of correlation analysis implied the consistency of PARAFAC and FRI analysis results on the same component. Similar result has also been reported previously (Kang et al. 2015).

Overall, C1 of PARAFAC model represented humic acid, and the variation of FIS from PARAFAC model was consistent with corresponding NIV in FRI analysis. PARAFAC model had the function of identifying the main fluorescent peaks from the 3D-EEM spectra, and FRI technique could realize the supplementary analysis of fulvic-acid and SMPs.

\section{Conclusions}

This study was based on a lab-scale BAF fed with simulated micro-polluted source water to explore the variation characteristics of DON in BAF when the gas-water ratio was set at 0, 0.5:1, 2:1, and 10:1, respectively. And spectral characterization under different gas-water ratios was also explained by 3D-EEM spectrum coupled with PARAFAC model and FRI technique.

As the gas-water ratio increased, DOC removal efficiencies gradually increased, but the increase was not unlimited. The variation of DON concentration in BAF to the gas-water ratio was consistent with that of DOC removal efficiency. As the gas-water ratio increased, the concentration of DON in BAF gradually increased, but the increase intensity gradually decreased. The optimal gas-water ratio in this study can be considered as $2: 1$.

The analysis result of PARAFAC model and FRI technique showed that the variation of FIS from PARAFAC model was consistent with corresponding NIV in FRI technique. The resistances of fluorescent substances identified by 3D-EEM to the gas-water ratio were expressed as: protein substances > humic acid and fulvic acid substances $\approx$ SMPs-like substances.

\section{Declarations}


Authors' contributions Jia Kang: Conceptualization, methodology, writing original draft, and funding acquisition; Gang-fu Song: Providing experimental venues and instrument, guiding experiments; Shu-li Liu: Data analysis, providing funds and draft review; Chu-qiong Song: Experiment conducting, data analysis; Gao Xu: Draft review and providing funds.

Funding We were grateful to the National High Technology Research and Development Program of China (863 Program) (2012AA062607), the National Natural Science Foundation of China (No. 51708214), the High-level Talent Introduction Program of North China University of Water Resources and Electric Power (40518), and the Key Promotion Project of Henan Province (202102310265) for funding this study. The authors also thank ZhongZhou Water Holding Co., I., td. for supporting this study.

Data availability All data generated or analyzed during this study were included in this published article (and its supplementary information files)

\section{Compliance with ethical standards}

Conflict of interest The authors declare that they have no conflict of interest.

Ethical approval All authors declared that they had no known competing financial interests or personal relationships that seemed to affect the work reported in this article. All authors followed the ethical responsibilities of this journal.

Consent to participate and publish All authors participated and approved the final manuscript to be published.

\section{References}

Aryal R, Lebegue J, Vigneswaran S, Kandasamy J, Grasmick A (2009) Identification and characterisation of biofilm formed on membrane bio-reactor. Separation \& Purification Technology 67(1): 86-94. https://doi.org/10.1016/j.seppur.2009.03.031

Bro R (1997) PARAFAC. Tutorial and applications. Chemometrics and Intelligent Laboratory Systems 38(2): 149-171. https://doi.org/10.1016/S0169-7439(97)00032-4

Bro R, Kiers HAL (2003) A new efficient method for determining the number of components in PARAFAC models. Journal of Chemometrics 17(5): 274-286. https://doi.org/10.1002/cem.801

Cao F, Zhu Y, Kieber DJ, Miller WL (2019) Distribution and photo-reactivity of chromophoric and fluorescent dissolved organic matter in the northeastern North Pacific Ocean. Deep Sea Research Part I: Oceanographic Research Papers 155: 103168. https://doi.org/10.1016/j.dsr.2019.103168

Carstea EM, Baker A, Bieroza M, Reynolds D (2010) Continuous fluorescence excitation-emission matrix monitoring of river organic matter. Water Research 44(18): 5356-5366.

https://doi.org/10.1016/j.watres.2010.06.036 
Chai L, Huang M, Fan H, Wang J, Jiang D, Zhang M, Huang Y (2019) Urbanization altered regional soil organic matter quantity and quality: insight from excitation emission matrix (EEM) and parallel factor analysis (PARAFAC). Chemosphere 220: 249-258. https://doi.org/10.1016/j.chemosphere.2018.12.132

Chang H, Chen C, Wang G (2013) Characteristics of C-, N-DBPs formation from nitrogen-enriched dissolved organic matter in raw water and treated wastewater effluent. Water Research 47(8): 27292741. https://doi.org/10.1016/j.watres.2013.02.033

Chen W, Westerhoff P, Leenheer JA, Booksh K (2003) Fluorescence excitation-emission matrix regional integration to quantify spectra for dissolved organic matter. Environmental Science \& Technology 37(24): 5701-5710. https://doi.org/10.1021/es034354c

Cui X, Chen C, Liu Y, Zhou D, Liu M (2019) Exogenous refractory protein enhances biofilm formation by altering the quorum sensing system: a potential hazard of soluble microbial proteins from WWTP effluent. Science of The Total Environment 667: 384-389.

https://doi.org/10.1016/j.scitotenv.2019.02.370

Fdz-Polanco F, Méndez E, Urueña M.A, Villaverde S, García P.A (2000) Spatial distribution of heterotrophs and nitrifiers in a submerged biofilter for nitrification. Water Research 34(16): 4081-4089. https://doi.org/10.1016/S0043-1354(00)00159-7

Gone DL, Seidel JL, Batiot C, Bamory K, Ligban R, Biemi J (2009) Using fluorescence spectroscopy EEM to evaluate the efficiency of organic matter removal during coagulation-flocculation of a tropical surface water (Agbo reservoir). Journal of Hazardous Materials 172(2-3): 693-699.

https://doi.org/10.1016/j.jhazmat.2009.07.052

Hasan HA, Abdullah SRS, Kamarudin SK, Kofli NT (2011) Response surface methodology for optimization of simultaneous $\mathrm{COD}, \mathrm{NH}_{4}{ }^{+}-\mathrm{N}$ and $\mathrm{Mn}^{2+}$ removal from drinking water by biological aerated filter. Desalination 275(1-3): 50-61. https://doi.org/10.1016/j.desal.2011.02.028

Hasan HA, Abdullah SRS, Kamarudin SK, Kofli NT, Anuar N (2013) Simultaneous and Mn ${ }^{2+}$ removal from drinking water using a biological aerated filter system: Effects of different aeration rates. Separation \& Purification Technology 118: 547-556. https://doi.org/10.1016/j.seppur.2013.07.040

Hasan HA, Abdullah SRS, Kamarudin SK, Kofli NT, Anuar N (2014) Kinetic evaluation of simultaneous COD, ammonia and manganese removal from drinking water using a biological aerated filter system. Separation and Purification Technology 130: 56-64. https://doi.org/10.1016/j.seppur.2014.04.016

Hu H, Liao K, Xie W, Wang J, Wu B, Ren H (2020a) Modeling the formation of microorganism-derived dissolved organic nitrogen (mDON) in the activated sludge system. Water Research 174: 115604. https://doi.org/10.1016/j.watres.2020.115604 
Hu H, Ma S, Zhang X, Ren H (2020b) Characteristics of dissolved organic nitrogen in effluent from a biological nitrogen removal process using sludge alkaline fermentation liquid as an external carbon source. Water Research 176: 115741. https://doi.org/10.1016/j.watres.2020.115741

Kang J, Du G, Gao X, Zhao B, Guo J (2014) Soluble microbial products from water biological treatment process: A review. Water Environment Research 86(3): 223-231.

https://doi.org/10.2175/106143013X13807328849413

Kang J, Ma T, Zhou Q, Gao J, Xiang Y (2015) New insight into DOC and DON in a drinking water biological aerated filter (BAF) by multimethod and correlation analysis of 3D-EEM. Analytical Methods 7(23): 98859893. https://doi.org/10.1039/c5ay02156a

Kang J, Liu S, Ma T, Gao X (2019) Production mechanism and characteristics of dissolved organic nitrogen derived from soluble microbial products (SMPs-DON) in a drinking water biological aerated filter. Water Science \& Technology Water Supply 19(6): 1994-2000. https://doi.org/10.2166/ws.2019.077

Li Y, Guo J, Li H, Song Y, Hou Y (2019a) Effect of dissolved oxygen on simultaneous removal of ammonia, nitrate and phosphorus via biological aerated filter with sulfur and pyrite as composite fillers. Bioresource Technology 296: 122340. https://doi.org/10.1016/j.biortech.2019.122340

Li Y, Xu H, He C, Shen Z, Chen W, Gao L, Lin C, Lin T, Lu C, Shi Q (2019b) Transformation and fate of dissolved organic nitrogen in drinking water supply system: A full scale case study from Yixing, China. Science of The Total Environment 673: 435-444. https://doi.org/10.1016/j.scitotenv.2019.03.309

Liao K, Hu H, Ma S, Ren H (2019) Effect of microbial activity and microbial community structure on the formation of dissolved organic nitrogen (DON) and bioavailable DON driven by low temperatures. Water Research 159: 397-405. https://doi.org/10.1016/j.watres.2019.04.049

Liu F, Zhao C, Zhao D, Liu G (2008) Tertiary treatment of textile wastewater with combined media biological aerated filter (CMBAF) at different hydraulic loadings and dissolved oxygen concentrations. Journal of Hazardous Materials 160(1): 161-167. https://doi.org/10.1016/j.jhazmat.2008.02.100

Liu H, Zhu L, Tian X, Yin Y (2017) Seasonal variation of bacterial community in biological aerated filter for ammonia removal in drinking water treatment. Water Research 123: 668-677.

https://doi.org/10.1016/j.watres.2017.07.018

Lu C, Li S, Gong S, Yuan S, Yu X (2015) Mixing regime as a key factor to determine DON formation in drinking water biological treatment. Chemosphere 139: 638-643.

https://doi.org/10.1016/j.chemosphere.2014.12.059

Ma T, Chen Y, Kang J, Gao X, Guo J, Fang F, Zhang X (2016) Influence of filtration velocity on DON variation in BAF for micropolluted surface water treatment. Environmental Science \& Pollution Research 23: 23415-23421. https://doi.org/10.1007/s11356-016-7578-0 
Rodríguez-Vidal FJ, García-Valverde M, Ortega-Azabache B, González-Martínez Á, Bellido-Fernández A (2020) Characterization of urban and industrial wastewaters using excitation-emission matrix (EEM) fluorescence: Searching for specific fingerprints. Journal of Environmental Management 263: 110396. https://doi.org/10.1016/j.jenvman.2020.110396

Shen Y, Xiao K, Liang P, Sun J, Huang X (2012) Characterization of soluble microbial products in 10 largescale membrane bioreactors for municipal wastewater treatment in China. Journal of Membrane Science 415-416(10): 336-345. https://doi.org/10.1016/j.memsci.2012.05.017

Stedmon CA, Bro R (2008) Characterizing dissolved organic matter fluorescence with parallel factor analysis: a tutorial. Limnology and Oceanography: Methods 6(11): 572-579. https://doi.org/10.4319/lom.2008.6.572b

Takasaki M, Kim H, Sato A, Okada M, Sudo R (1990) Submerged biofilm process as a pre-treatment for polluted raw water for tap water supply. Water Science \& Technology 22(1-2): 137-148.

https://doi.org/10.1016/0043-1354(90)90075-H

Teng J, Shen L, Xu Y, Chen Y, Lin H (2020) Effects of molecular weight distribution of soluble microbial products (SMPs) on membrane fouling in a membrane bioreactor (MBR): Novel mechanistic insights. Chemosphere 248: 126013. https://doi.org/10.1016/j.chemosphere.2020.126013

Wu M, Liang Y, Peng H, Ye J, Wu J, Shi W, Liu W (2019) Bioavailability of soluble microbial products as the autochthonous precursors of disinfection by-products in aerobic and anoxic surface water. Science of the Total Environment 649: 960-968. https://doi.org/10.1016/j.scitotenv.2018.08.354

Xu B, Ye T, Li D, Hu C, Gao N (2011) Measurement of dissolved organic nitrogen in a drinking water treatment plant: Size fraction, fate, and relation to water quality parameters. Science of The Total Environment 409(6): 1116-1122. https://doi.org/10.1016/j.scitotenv.2010.12.016

Yamashita Y, Tanoue E (2003) Chemical characterization of protein-like fluorophores in DOM in relation to aromatic amino acids. Marine Chemistry 82(3-4): 255-271. https://doi.org/10.1016/S03044203(03)00073-2

Yang B, Wang J, Wang J, Xu H, Song X, Wang Y, Li F, Liu Y, Bai J (2017) Correlating microbial community structure with operational conditions in biological aerated filter reactor for efficient nitrogen removal of municipal wastewater. Bioresource Technology 250: 374-381.

https://doi.org/10.1016/j.biortech.2017.11.065

Yang Q, Cui B, Zhou Y, Li J, Liu Z, Liu X (2020). Impact of gas-water ratios on $\mathrm{N}_{2} \mathrm{O}$ emissions in biological aerated filters and analysis of $\mathrm{N}_{2} \mathrm{O}$ emissions pathways. Science of The Total Environment. https://doi.org/10.1016/j.scitotenv.2020.137984 
Yu X, Ye L, Wei G (2008) Modeling the formation of soluble microbial products (SMP) in drinking water biofiltration. Water Science and Engineering 1(3): 93-101. https://doi.org/10.3882/j.issn.16742370.2008.03.010

Yue X, Yu G, Lu Y, Liu Z, Li Q (2018) Effect of dissolved oxygen on nitrogen removal and the microbial community of the completely autotrophic nitrogen removal over nitrite process in a submerged aerated biological filter. Bioresource Technology 254: 67-74. https://doi.org/10.1016/j.biortech.2018.01.044

Zhang H, Zhang K, Jin H, Gu L, Yu X (2015) Variations in dissolved organic nitrogen concentration in biofilters with different media during drinking water treatment. Chemosphere 139: 652-658. https://doi.org/10.1016/j.chemosphere.2014.10.092

Zhang Q, Wang C, Jiang L, Qi J, Wang J, He X (2018) Impact of dissolved oxygen on the microbial community structure of an intermittent biological aerated filter (IBAF) and the removal efficiency of gasification wastewater. Bioresource Technology 255: 198-204.

https://doi.org/10.1016/j.biortech.2018.01.115

Zhang J, Song F, Li T, Xie K, Yao H, Xing B, Li Z, Bai Y (2019) Simulated photo-degradation of dissolved organic matter in lakes revealed by three-dimensional excitation-emission matrix with regional integration and parallel factor analysis. Journal of Environmental Sciences 90: 310-320. https://doi.org/10.1016/j.jes.2019.11.019

Zhuang W, Chen W, Cheng Q, Yang L. (2021) Assessing the priming effect of dissolved organic matter from typical sources using fluorescence EEMs-PARAFAC. Chemosphere 264: 128600. https://doi.org/10.1016/j.chemosphere.2020.128600

\section{Figures}




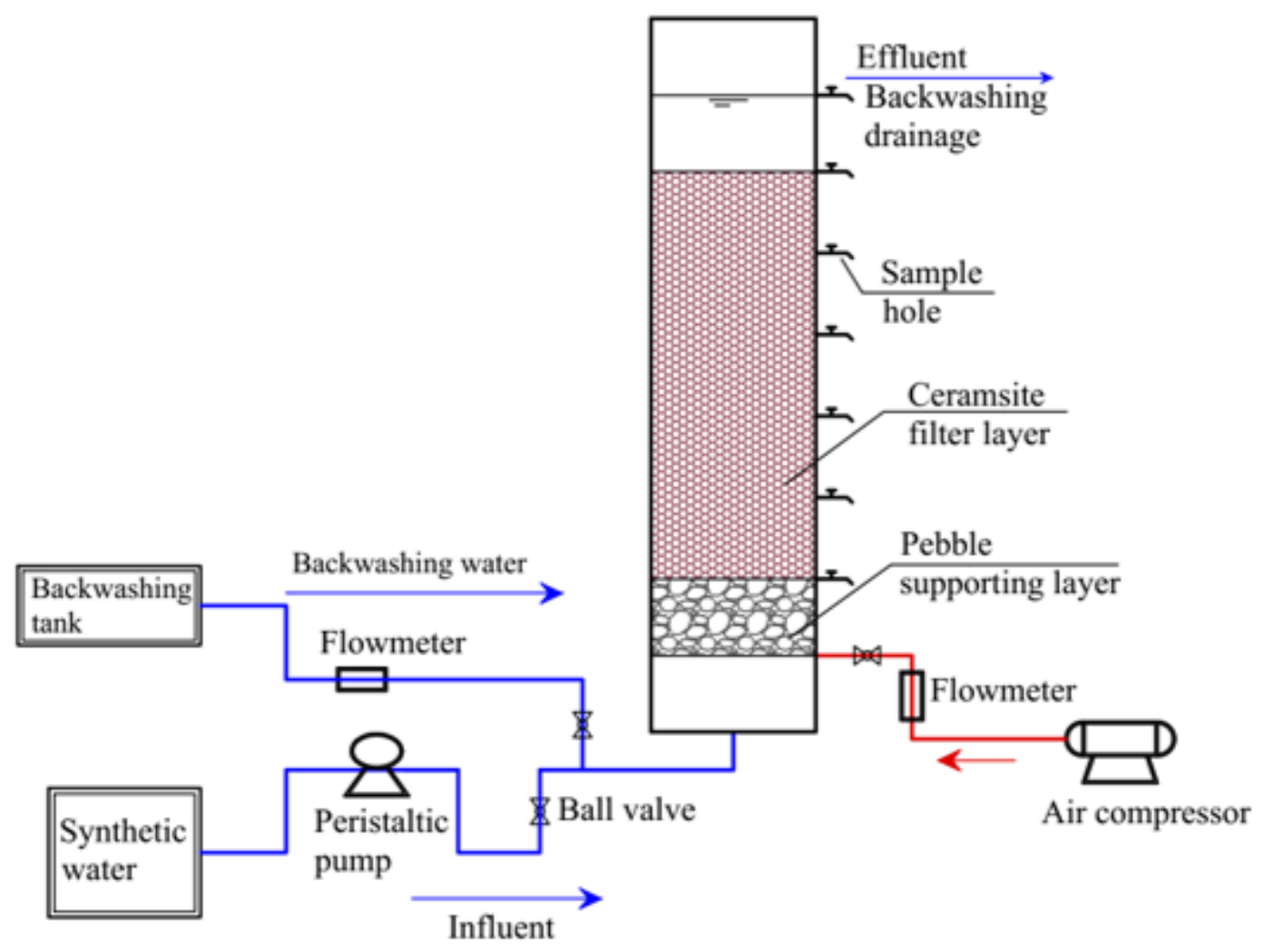

Figure 1

Schematic diagram of the BAF reactor

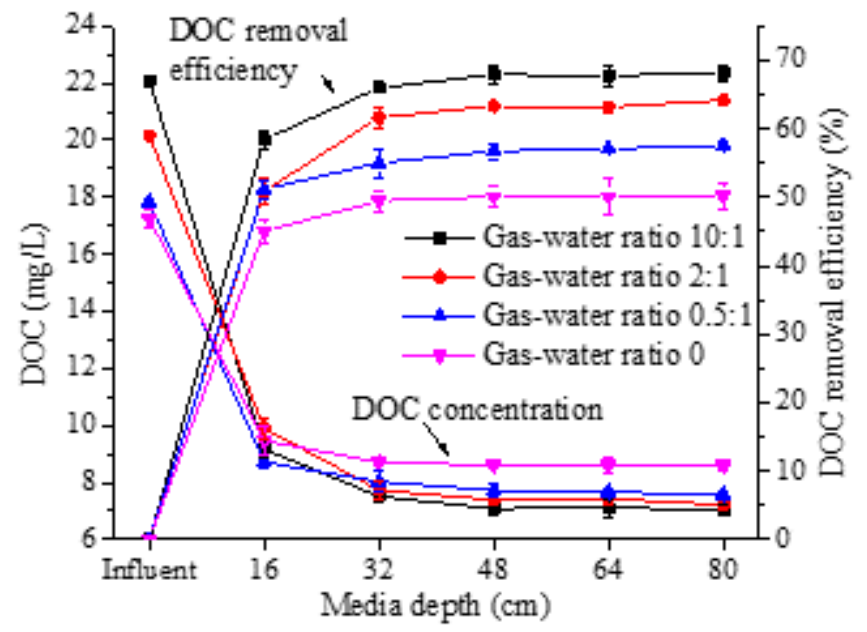

Figure 2

Variations of DOC concentrations and DOC removal efficiencies in the BAF under different gas-water ratios 


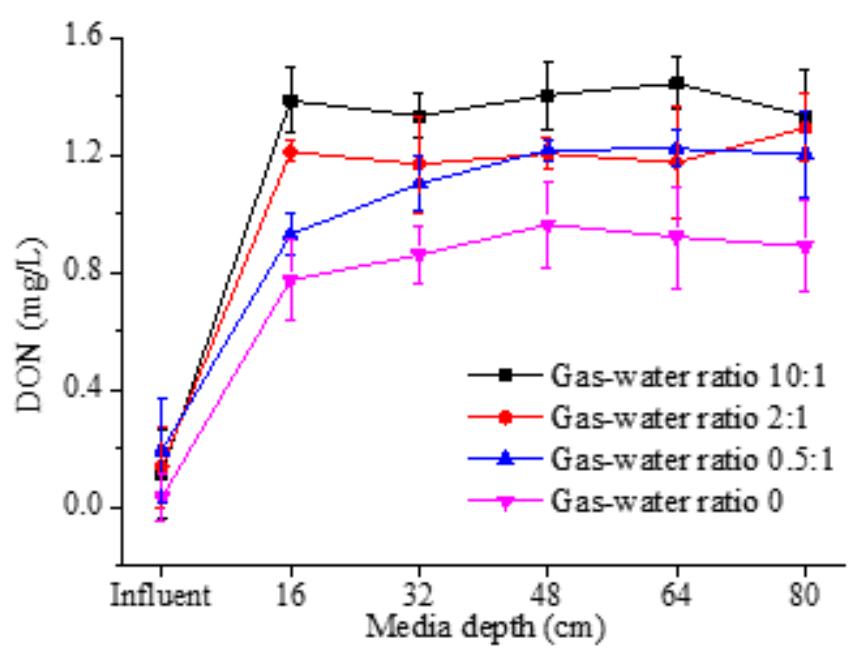

Figure 3

Variations of DON concentrations in the BAF under different gas-water ratios
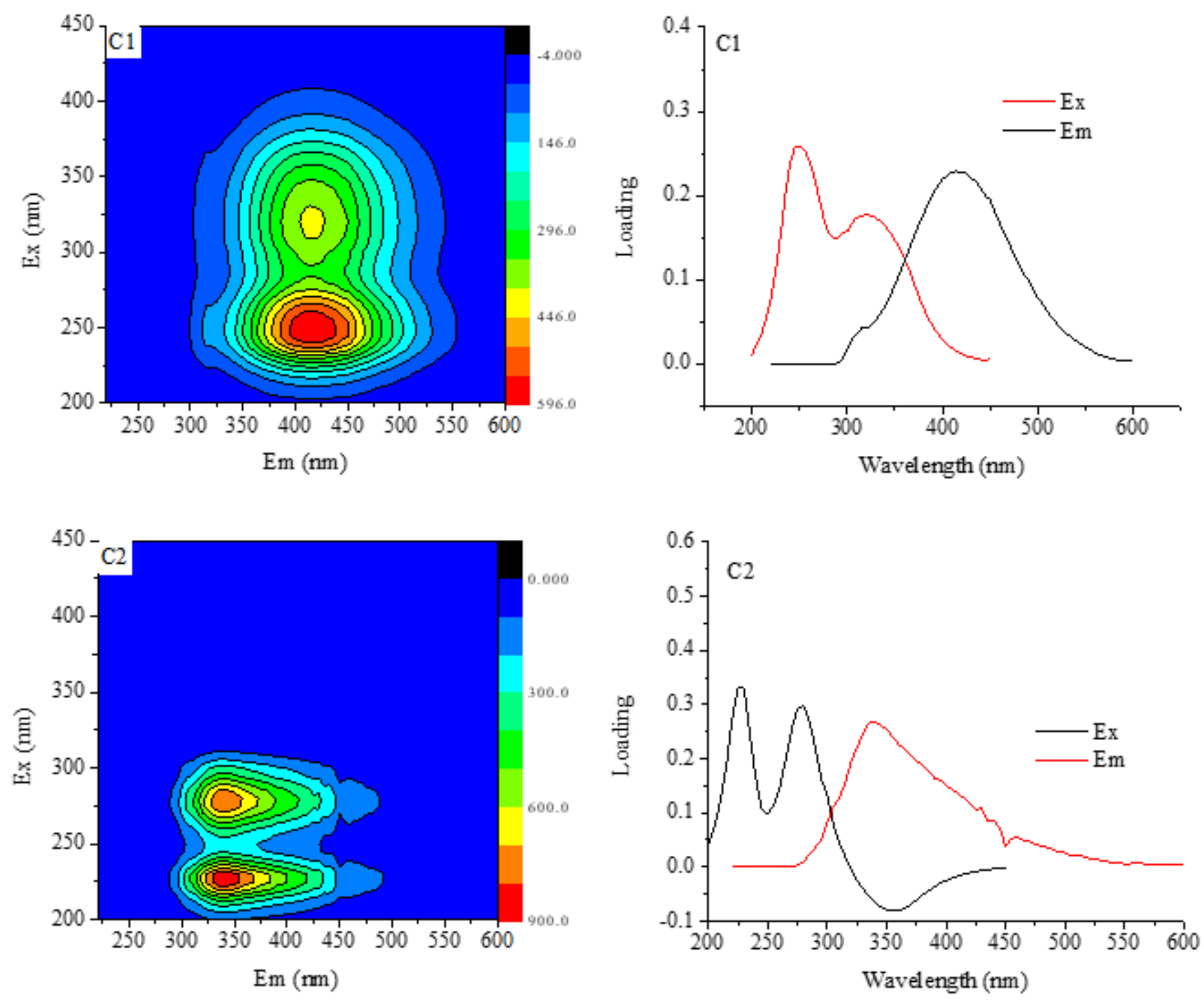
Figure 4

3D-EEM spectra and wavelength loadings of the two components decomposed by PARAFAC model

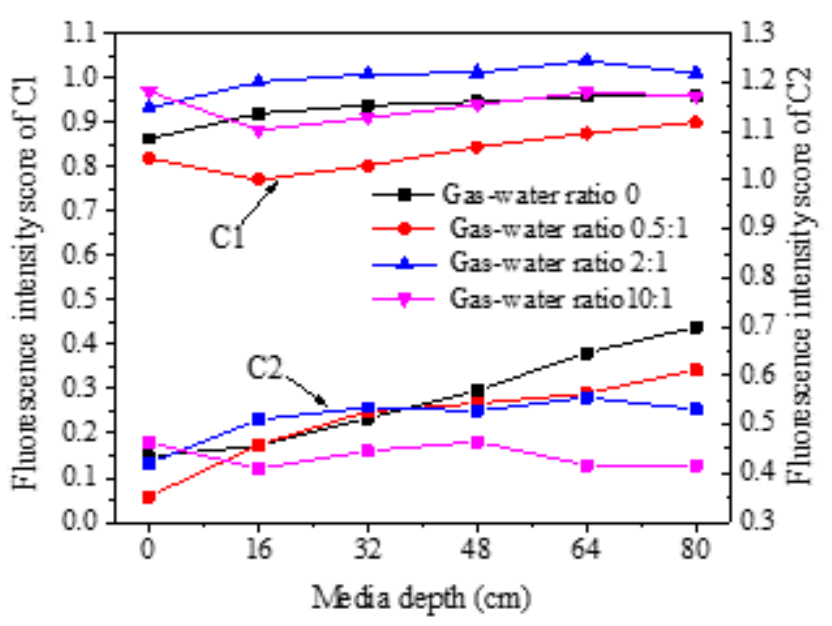

Figure 5

Variations of fluorescence intensity score under different gas-water ratios 

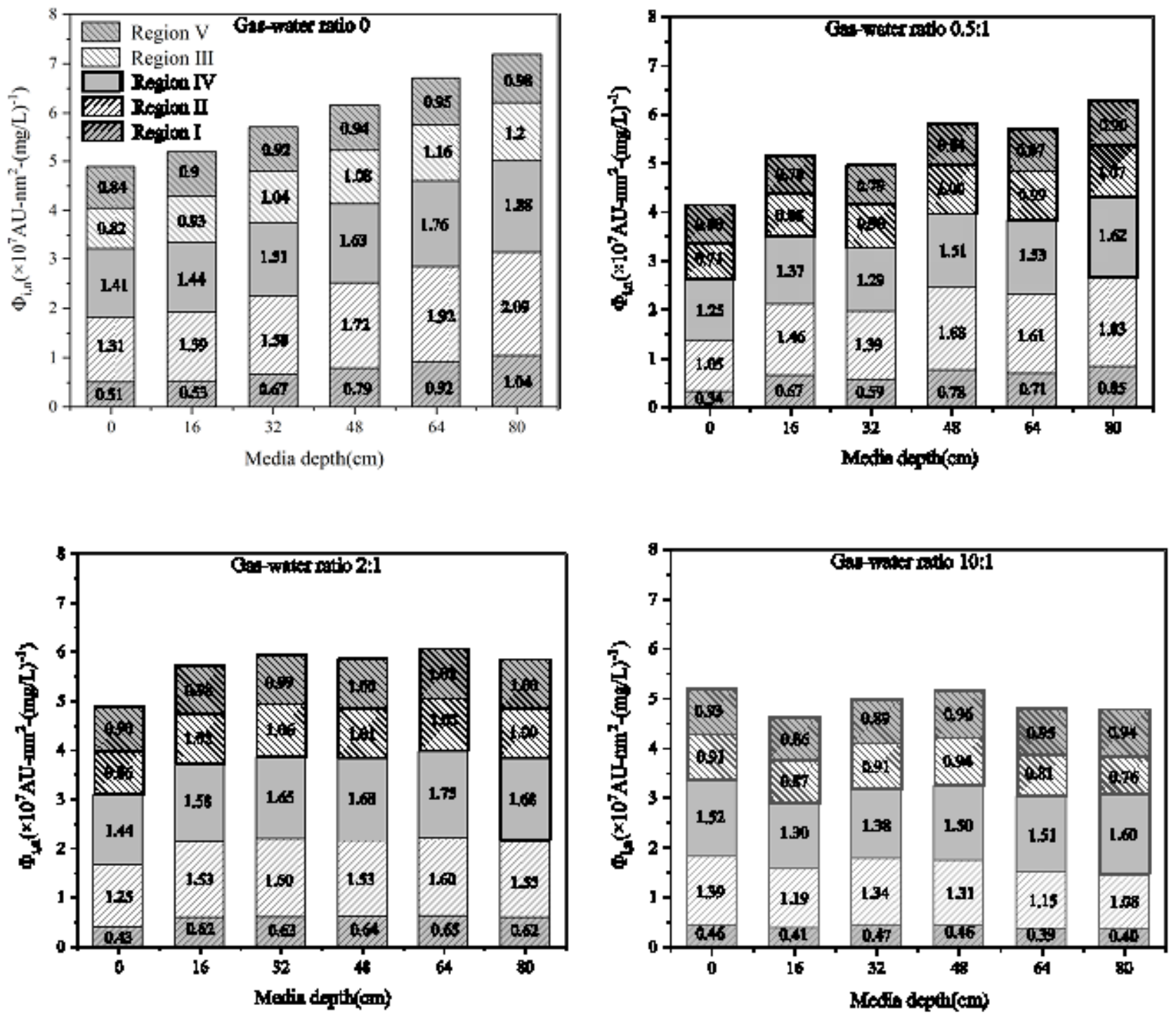

Figure 6

Distribution of $\emptyset(\mathrm{i}, \mathrm{n})(\times 107, \mathrm{AU}-\mathrm{nm} 2-(\mathrm{mg} / \mathrm{L})-1)$ for samples under different gas-water ratios
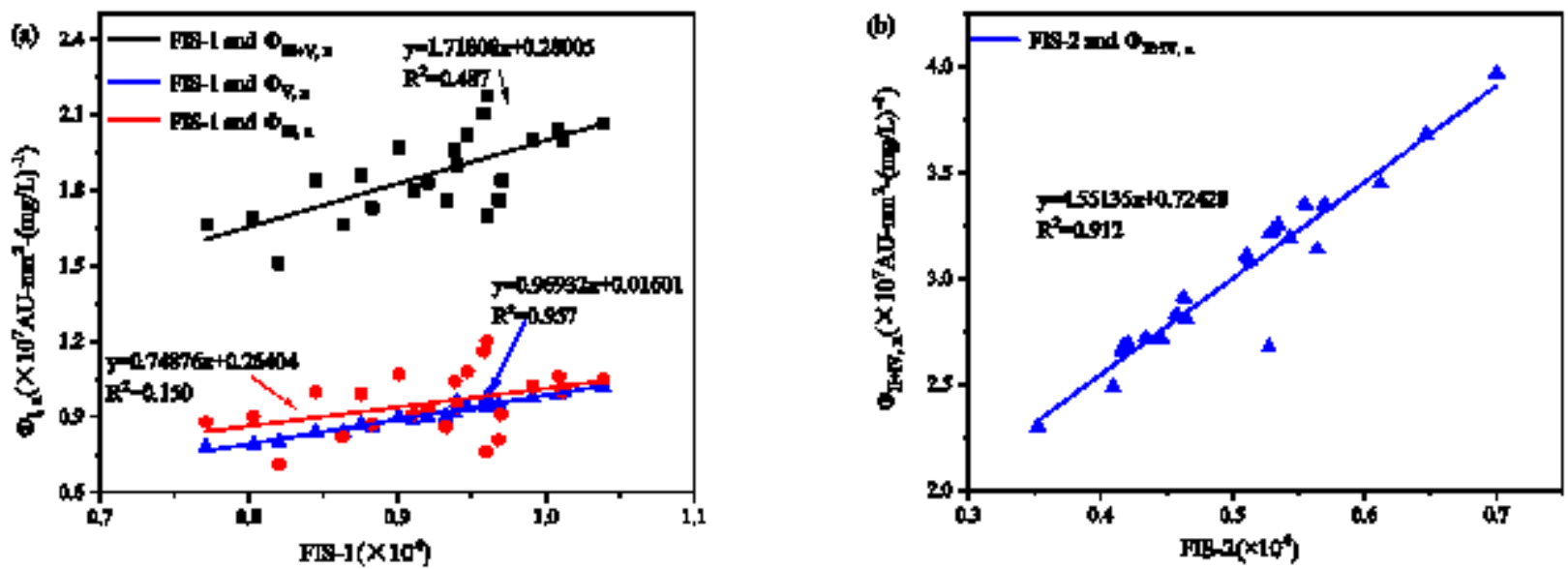
Figure 7

Correlations between FIS and NIV from PARAFAC model and FRI technique on corresponding components

\section{Supplementary Files}

This is a list of supplementary files associated with this preprint. Click to download.

- Supplementarylnformation.pdf 